\title{
Cross-cultural communication of the Indonesian students in China
}

\author{
Uspal Jandevi ${ }^{\text {a,1,*}, ~ M a h w a s h ~ Z a r e e n ~}{ }^{\text {b,2 }}$ \\ a Nanjing Normal University, Wenyuan Road Qixia District, Nanjing 210046, P.R. China \\ b Punjab University, Canal Rd, Lahore, Punjab 54590, Pakistan \\ ${ }^{1}$ 30185309@stu.njnu.edu.cn *; ${ }^{2}$ mzareen.786@ hotmail.com \\ * corresponding author
}

\section{ARTICLE INFO}

Article history

Received 2020-04-22

Revised 2020-05-26

Accepted 2020-06-04

Keywords

Communication

Cross-Cultural

Cultural Shock

Foreign Students

China

\section{ABSTRACT}

This paper aims to find out how the process and the steps taken by Indonesian students studying in China to overcome culture shock during their study in China. This research seeks to provide answers to cultural shock events that arise from a process of cross-cultural communication. The data were obtained by conducting an in-depth interview process and then processed optimally using the Speech Codes Theory (SCT) initiated by Gerry Philipsen. This study shows that Indonesian students tend to cope with cultural shock events from cross-cultural communication processes when mingling with other community members.

This is an open access article under the CC-BY-SA license.

\section{Introduction}

Entering the beginning of the 21st century, China began to feel the effects of the cultural revolution. They had declared during the reign of Mao Zhedong in 1976. It was proving the face of China, which has now become more open and modern. Even though so far, not many people realize that China will transform into one of the world's big countries because of its unpopular ideology [1]. However, actually, some observers of the world political economy had predicted the rise of China in the early 21st century, when the whole world suspected that the United States would emerge victorious when the globalization valve was opened, James Meredith once said that the world was wrong to think like that because it is not the United States but China or India that will win the global era. Between the two countries, China is the most likely [2]. Now it seems that Meredith predicted came true that mentioned China is not only a champion in the Global Era but also slowly becoming an Adi Power country shifting the position of the United States. Its expansion is slowly reaching countries around it [3].

As a country with an excellent scientific tradition since the historical Confucius era, China in the modern era also has an education quality that cannot be underestimated, as evidenced by the number of Chinese universities included in the ranks of the world's top 1000 universities [4]. Students from various parts of the world began to make China a destination for continuing education, including students from Indonesia. One of the favorite cities to encourage study in China is Nanjing, the capital of China, before finally moving to Nanjing because of Nanjing's fall into the hands of Japan during the Second World War [1].

Based on a census conducted by the Nanjing China Regional Association of Indonesian Students (PPIT) in 2019, the number of Indonesian students in the city of Nanjing studying from bachelor 
until post-Doctoral has reached 509 people. This amount has not been added to the number of nondegree students who are not insignificant [5].

In addition to Indonesian students, there are also students from ASEAN countries such as Malaysia, Timor Leste, Brunei, the Philippines, Thailand, Cambodia, and Myanmar. As a citizen of a country in Southeast Asia with strengths in terms of religion and traditional cultural roots, it is necessary to make extra adjustments to live in other countries, like China [6].

Students from ASEAN countries in China, including those in Nanjing City, should familiarize themselves with living there for a long time. Cross-cultural communication activities and cultural commotion are experienced not only when they come into contact with residents but also when they come into contact with other international students. Some people managed to familiarize themselves with their cross-cultural communication activities and overcome the cultural upheaval that befell them. Some other ASEAN students still need more time to get used to [7].

That is why this research aimed to find on how cross-cultural communication of students from ASEAN countries, especially Indonesian Students, to cope with cultural upheaval during their education in China. The results of this research will be useful as a guide for Indonesian students and other ASEAN countries who wish to study in China or other countries.

\section{Theoritical Framework}

Previously there has been research conducted by Cupsa [8], a professional social psychologist in Timisoara Romania. He conducted research on how human behavior when identity is exposed to exposure to a culture that is completely foreign to him, as well as how the social implications caused by someone who is experiencing a culture shock. In his research he concluded that when a person is in a new environment, his identity will be very sensitive in dealing with various phenomena in his new environment.

Then in another study Pyvis and Chapman [9] two researchers from Curtin University of Technology Australia and the University of Western Australia. He conducts research on how crosscultural communication is carried out by international students. He said that one of the groups that most often experienced cultural shock from cross-cultural communication was international students who came to a region that was completely different in terms of culture and maybe even technology when compared to their home country.

In 1994 Michael James Winkelman [10] a researcher from Arizona State University conducted a study of how a cultural shock occurred between the two parties, both those who came and the people whose territory they visited. Then he said in the results of his research that the failure of someone to overcome the culture commotion internally would potentially lead to stress and externally it would lead to conflicts between cultures. Then the commotion of the culture is not something that should be considered trivial.

Michael James's research above is strengthened by research conducted by Alfred Presbitero researcher from Deakin University, Melbourne, Australia. He argued that it is important for an international student in addition to only having academic intelligence must have high social intelligence. In his research also showed that international students who have high social intelligence have a tendency to be able to complete their studies better than international students who only have academic intelligence [11].

\subsection{Cross-Cultural Communication}

Cross-cultural communication is there a process of exchanging messages from individuals to other individuals where the individuals come from different cultural backgrounds [12]. In Face Negoitation Theory Ting Toomey and Kurogi argued that in cross-cultural communication activities there are at least ten meanings to be conveyed, namely: happiness, surprise, fear, anger, sadness, disgust, reproach, interest, fascination, and determination [13]. Both of them also said that modern man cannot escape from the fact that he must cross-cultural communication in his life's opportunity, and this is not easy, so don't be surprised if humans will find conflict when the cross-cultural communication process takes place [14]. 
That is why sometimes when conducting cross-cultural communication someone will be very careful. In Expectancy Violations Theory Burgoon said that when in a foreign environment and surrounded by strangers with cultures that are also strangers, individuals will provide strict limits on their personal space (personal space). The personal space can be more extensive or narrower adjusted to the level of comfort while in the midst of that alienation. Humans will be very sensitive to protect the personal space because it greatly affects their comfort [15].

Within a certain period of time the individual begins to try to adjust, the strategy begins to be arranged so that he can be more flexible in carrying out cross-cultural communication activities [16]. Howard Giles conveyed in The Theory of Communication Accommodation that humans will bring up assumptions in their heads, related to what he must do to be able to mingle and interact with other humans with cultures that are different from him. Efforts to get a positive image continue to be pursued by these individuals so they can continue to maintain their relationship with other humans as social creatures [17].

However, in making efforts to build a positive image and open a path of healthy interaction in cross-cultural communication, humans must do it calmly, these efforts will not succeed if the anxiety still comes excessively [18]. William Gundykunst in anxiety management theory said that cross-cultural communication would work effectively if the communicator could manage his anxiety appropriately [19].

Whereas culture schock is a feeling experienced by someone when he is in a new place, a place that he has never been to before [20]. This cultural shock can include many things, from technology to everyday views of the community that have never been found in their original place [18]. For example, people who have been living in communities that are still actively using the traditional payment system, will certainly be surprised when they arrive in an area where the citizens have become cashless society, no longer using cash in transactions, just simply scanning a barcode using a cellphone [8].

Many people assume that the Culture Concussion situation is a situation that is not good for someone, but actually someone who has a culture shock has the opportunity to improve the quality of himself [21]. That is because actually when a culture shock hits someone it means that the body and soul are receiving an injection of new knowledge that they have never experienced or know about. Until the anxiety and anxiety that he feels can be likened to a body that is receiving the effects of vaccine injections, which for some time the body will feel uncomfortable but in the end the immune system increases, roughly like that of the parable of people who are experiencing a culture shock.

In general, a person will experience three phases in a culture shock condition [22], including:

a) Introductory Phase. In this phase a person will feel one of two things; comfort or fear. In this phase those who feel comfortable are those who consider that the place they just occupied is better than the place of origin, and vice versa.

b) Negotiation phase. In this phase there begins to feel a longing for his old place of residence, a feeling as if something is missing as he leaves his place of origin slowly appears. This is a situation that will determine whether a person will be able to survive or he will give up in his new environment.

c) Under Control Phase. If he succeeds in passing the two phases above then in this phase the person no longer feels a positive or negative impression on his new environment, the new environment is no longer a foreign culture for him but has become his second culture.

\subsection{Privacy}

Talking about intercultural communication and culture shock, we will undoubtedly discuss privacy [23]. Privacy is the level of interaction or openness desired by someone in a specific condition or situation. The desired level of confidentiality involves openness or closure, a desire to interact with others, or instead wants to avoid or try to be challenging to reach by others [24].

Privacy can also be said as an ability to control interactions, the ability to obtain choices, and the ability to achieve the desired communication. Privacy should not be seen merely as a physical withdrawal of someone from other parties to be alone. Privacy shows the choice to avoid 
involvement with others and their social environment. In other words, privacy is the process of controlling selective access to oneself and access to others [25].

The relationship between privacy, personal space, and territoriality with the environment, namely: humans need privacy for themselves so that he feels comfortable. Other people do not know what activities are carried out, and humans also need personal space so they can be free from fatigue and distress and can become a place where humans withdraw themselves from the crowd of people around them. Besides that, humans also need territoriality, where they have a place for themselves and those closest to them. Territoriality behavior about the environment can be seen in the use of physical elements to mark the boundary of one's territory, for example, yard fences. This territoriality is divided according to its nature, from the private to the public. The point is someone needs privacy, personal space, and territoriality to get comfort for themselves. When individuals perceive their territory as their territory, it means they have the possibility to prevent any discomfort in their area [26].

\section{Method}

This paper uses a descriptive qualitative approach, which is a study that leads to a detailed and in-depth description of the condition portrait of what actually happens according to what is happening in the field [27]. The author took samples of Indonesian students studying in the city of Nanjing and interviewed them with in-depth interviewing techniques. This research uses the case study method. Case studies are research methods that use a variety of data sources (as much data as possible) that can be used to research, describe and comprehensively explain various aspects of individuals, groups, programs, organizations, or events systematically. Examining these various data sources requires a variety of data collection instruments [28]. Therefore, researchers can use indepth interviews, participatory observation, documentation, questionnaires (survey results), records, physical evidence, and others [29]. In this paper, interviewing Indonesian students in Nanjing in depth. The questions asked are not structured, thus providing an opportunity for writers to ask more deeply than the answers given by respondents [30]. The author also participates in observations, where the author is directly involved in the activities of Indonesian students in Nanjing by observing them and interviewing Indonesian students in Nanjing.

\section{Results and Discussion}

The social relations of Indonesian students in Nanjing are relatively straightforward. They can follow the lesson calmly without any significant obstacles. Generally, this convenience is faced by groups of students who take lectures in international classes through exchange programs. Forms of student exchange will be easier to maintain communication. Especially for students from Indonesia who can accept differences, ready. With conditions and situations and easily enjoying life travel abroad easily, Indonesian students who take international classes are highly tolerated in conducting academic activities like getting a special holiday allotment and leaving the class for Friday prayers, especially if half the class is Muslim.

On several campuses in Nanjing City, Muslims are dominated by students from Bangladesh, Pakistan, Tajikistan, Saudi Arabia, and several African countries such as Tanzania, Sudan, Nigeria, and Sierra Leone. Intercultural communication has two main functions, namely the personal function and social function. Personal functions are broken down into the function of expressing social identity, the function of social integration, increasing knowledge (cognitive), and the function of escape (escape). Simultaneously, the social function includes the function of supervision, the function of bridging or connecting, the function of socialization, and the function of entertaining.

Indonesian students in Nanjing have a unique social identity in showing themselves in their social environment. For women, wearing the hijab in Nanjing as a religious identity does not need to be mentioned anymore. Those who wear the hijab feel comfortable with this identity-no need to explain anything about themselves when gathering with other students of different religions. In contrast to female students who do not wear headscarves (veils), they must repeatedly explain their religion in a large group between cultures.

The advantages faced by Indonesian students who wear the hijab arise in daily interactions outside the campus. When they shop, walk or do activities on campus, though. Muslim students 
from other countries or Muslim workers will more easily recognize and greet. Friendship is established because of the identity they show when they are in public. In large groups, it is not difficult for them to communicate the problem of consumption. Without having to mention halal food, the committee will provide halal food or vegetarian menus for them. Unlike Muslim students who do not wear the hijab, they must repeatedly state their beliefs.

Muslim students who did not close their heads said they had difficulty living in Nanjing. Food, cultural beliefs cannot be denied. Those who do not cover their heads also can not avoid when offered alcoholic beverages, invitations to eat at restaurants in any place. For them to first explain the position of the religion, they profess to avoid things that are not desirable. Muslim students who do not wear the hijab also stated that their association could be more easily accepted because it is not considered conservative as those who wear the hijab. These conditions provide advantages in establishing social relations with local and international communities.

In comparison, those who wear the hijab say that their obstacles in socializing are limited. Many things are considered in a variety of ways, including gathering events conducted on campus. Gathering events are generally coordinated by groups of students from western countries and identical to the bar'sbar's event. Even though they don'tdon't drink with them, the presence of women with headscarves in bars is unusual and looks bad.

Constraints in communication arise when unable to communicate intentions and goals to local and foreign communicants. Generally, local Chinese and Muslim communities use Mandarin as a language of communication between people. Not all students from Indonesia can actively communicate in Mandarin because they are in an English class and have not taken Mandarin classes before.

Indonesia's background with a high context culture will be a comparison factor if faced with China that embraces a low context culture. If they are accustomed to speaking indirectly in Indonesia, then the Chinese will more often talk to the point according to their cultural characteristics. The most common Indonesian Muslim student communication constraints occur most commonly faced with physiological and semantic obstacles. When Language is a communication tool but it is a common obstacle faced by students from Indonesia.

Where the difficulty of expressing Language is more dominant in its environment, common things happen only when communicating when shopping. Mispronounced in the Mandarin language can lead to errors of meaning. Tone errors during pronunciation can change the meaning of the word in question. In the process, the perception factor also cannot be separated when someone communicates with the speaker when male Muslim students are generally cautious about asking local female students because the meaning issued can change. For example, 请问 (read: qing we) for "ask a question" with 轻吻（Read: qing wen） for "asking a kiss". The mistake not only caused problems for the communicator but also a group of students from Indonesia in particular.

Other obstacles occur when shopping. Pronunciation errors in understanding Chinese characters and distinguishing the meaning of one word from another is a challenge in itself. The most common challenge faced by students from Indonesia is reading the composition on food packaging that does not have a halal label. Both from imported food and halal food.

\section{Conclusion}

This research was aimed to observe the International students from the ASEAN countries in China, especially whose from Indonesia. Indonesian students, who are predominantly Muslim, can also provide a good explanation of what they are allowed or forbidden to do or consume so that Chinese people and other students could understand. Cultural differences, especially in terms of diversity, are not a problem for Indonesian students in China, but the big problem is when they have to use Chinese in their daily lives. Chinese words and sentence structures can be mastered quickly by Indonesian students, but not by their intonation. The Chinese language is not just a mention of words but also the art of issuing notes. The wrong tone will bring up the wrong word meaning, as well. This has become a scourge for Indonesian students. To sum up, Indonesian students tend to be able to adjust to the local culture live. 


\section{References}

[1] D. Fadillah, "Belt Road Initiative in the Simulacra Analysis (Indonesia - China Relationship in the Perspective of Indonesian Students in Nanjing City)," ASPIKOM, vol. 5, no. 1, pp. 63-71, 2020.

[2] R. Meredith, The Elephant and the Dragon: The rise of India and China and What it Means for All of Us. New York: W. W. Norton \& Company, Inc., 2007.

[3] A. Pranoto, "Jalur Sutera Modern Adalah Geostrategi China," Nusantara News, 2017. [Online]. Available: https://nusantaranews.co/jalur-sutera-modern-adalah-geostrategi-china/.

[4] Luke Nolan, "Five Reasons Why You Should Study Abroad In China," G-meo, 2014. [Online]. Available: http://www.gmeochina.com/five-reasons-why-you-should-study-abroad-in-china/.

[5] F. Muzakki, "Di Balik Layar Projek Global: Latar Belakang, Motivasi, dan Cakupan Inisiative 'Belt and Road," in Indonesia dalam The Belt and Road Initiative, F. Muzakki, Ed. Jakarta: PPI Tiongkok, 2019, pp. $8-19$.

[6] A. Romdoni, "Inisiatif Belt and Road: Dari Pengetahuan Lokal ke Kesejahteraan Global," in Indonesia dalam The Belt and Road Initiative, F. Muzakki, Ed. Jakarta: PPI Tiongkok, 2019, pp. 20-31.

[7] S. Pramono, "The Belt and Road Initiative \& Global Maritim Fulcrum: Perbandingan Pengalaman dari Pengalaman Tiongkok," in Indonesia dalam The Belt and Road Initiative, Fadlan Muzakki, Ed. Jakarta: PPI Tiongkok, 2019, pp. 155-170.

[8] I. Cupsa, "Culture Shock and Identity," Trans. Anal. J., vol. 48, no. 2, pp. 181-191, Apr. 2018, doi: 10.1080/03621537.2018.1431467.

[9] D. Pyvis and A. Chapman, "Culture shock and the international student "offshore," J. Res. Int. Educ., vol. 4, no. 1, pp. 23-42, Apr. 2005, doi: 10.1177/1475240905050289.

[10] M. Winkelman, "Cultural Shock and Adaptation," J. Couns. Dev., vol. 73, no. 2, pp. 121-126, Nov. 1994, doi: 10.1002/j.1556-6676.1994.tb01723.x.

[11] A. Presbitero, "Culture shock and reverse culture shock: The moderating role of cultural intelligence in international students' adaptation," Int. J. Intercult. Relations, vol. 53, pp. 28-38, Jul. 2016, doi: 10.1016/j.ijintrel.2016.05.004.

[12] C. A. Nuraflah, "Hambatan komunikasi antar budaya," Majalah Ilmiah Politeknik Mandiri Bina Prestasi, Medan, pp. 149-155, 2017.

[13] S. Ting-toomey and A. Kurogi, "Facework competence in intercultural conflict: an updated facenegotiation theory," Int. J. Intercult. Relations, vol. 22, no. 2, pp. 187-225, 1998, doi: https://doi.org/10.1016/S0147-1767(98)00004-2.

[14] D. Fadillah, L. Zhenglin, and D. Hao, "Social Media and General Elections in Malaysia 2018 and Indonesia 2019," J. Komun. ISKI, vol. 4, no. 1, pp. 1-8, 2019, doi: 10.25008/jkiski.v4i1.255.

[15] J. K. Burgoon, "A communication model of personal space violations: explication and an initial test," Hum. Commun. Res., vol. 4, no. 2, pp. 129-142, 1978, doi: https://doi.org/10.1111/j.14682958.1978.tb00603.x.

[16] K. Jaya, "Venezuela's communication dynamics in rejection of humanitarian assistance from United States of America," Int. J. Commun. Soc., vol. 1, no. 1, pp. 26-33, 2019, doi: 10.31763/ijcs.v1i1.5.

[17] H. Giles and T. Ogay, "Communication Accommodation Theory," in Explaining Communication: Contemporary Theories and Exemplars, New Jersey: Lawrence Erlsbaum, 2007, pp. 293-310.

[18] D. Fadillah, L. Zhenglin, and D. Hao, "Big Data and the Revolution of Political Campaign in Indonesia," in Proceedings of the 2019 Ahmad Dahlan International Conference Series on Education \& Learning, Social Science \& Humanities (ADICS-ELSSH 2019), 2019, doi: 10.2991/adics-elssh19.2019.19.

[19] W. Gudykunst, “Anxiety/Uncertainty Management Theory,” in A First Look at Communication Theory, New York: McGraw-Hill Education, 2014, pp. 426-438.

[20] F. F. Lotan, "Making a positive internet through Socmed Agawe Guyub," Int. J. Commun. Soc., vol. 1, no. 1, pp. 9-16, 2019, doi: 10.31763/ijcs.v1i1.22. 
[21] T. Milstein, "Transformation abroad: Sojourning and the perceived enhancement of self-efficacy," Int. J. Intercult. Relations, vol. 29, pp. 217-238, 2005, doi: 10.1016/j.ijintrel.2005.05.005.

[22] T. M. Steinfatt and D. M. Millette, "Intercultural communication," in An Integrated Approach to Communication Theory and Research, Third Edition, 2019.

[23] S. T. Moreman and S. R. Briones, "Deaf Queer world-making: A thick intersectional analysis of the mediated cultural body," J. Int. Intercult. Commun., vol. 11, no. 3, pp. 216-232, Jul. 2018, doi: 10.1080/17513057.2018.1456557.

[24] K. B. Little, "Personal space," J. Exp. Soc. Psychol., vol. 1, no. 3, pp. 237-247, Aug. 1965, doi: 10.1016/0022-1031(65)90028-4.

[25] R. Welsch, C. von Castell, and H. Hecht, "The anisotropy of personal space," PLoS One, vol. 14, no. 6, p. e0217587, Jun. 2019, doi: 10.1371/journal.pone.0217587.

[26] E. Lough, E. Flynn, and D. M. Riby, "Personal Space Regulation in Williams Syndrome: The Effect of Familiarity," J. Autism Dev. Disord., vol. 46, no. 10, pp. 3207-3215, Oct. 2016, doi: 10.1007/s10803016-2864-8.

[27] D. Fadillah, "Strategi komunikasi pembentukan budaya organisasi," Humanika, vol. 14, no. 1, 2014, doi: https://doi.org/10.21831/hum.v14i1.3327.

[28] Sugiyono, Manajemen Metode Penelitian. Yogyakarta: Alfabeta, 2013.

[29] N. Hadari, Metode Penelitian Bidang Sosial. Yogyakarta: Gajah Mada University Press, 2003.

[30] D. Mulyana, Metode Penelitian Kualitatif. Bandung: Rosdakarya, 2002. 